\title{
Understanding of Symmetry: Measuring the Contribution of Virtual and Concrete Models for Students with Different Spatial Abilities
}

\author{
Thayban Thayban, ${ }^{1}$ Habiddin Habiddin, ${ }^{1,2 \star}$ Yudhi Utomo ${ }^{1}$ \\ and Muarifin Muarifin ${ }^{3}$ \\ ${ }^{1}$ Graduate Program, Department of Chemistry, Faculty of Mathematics and Natural Sciences, \\ Universitas Negeri Malang - Indonesia \\ ${ }_{2}^{2}$ PUI PT Disruptive Learning Innovation (DLI), Universitas Negeri Malang - Indonesia \\ ${ }^{3}$ Faculty of Sport Science, Universitas Negeri Malang - Indonesia \\ *Corresponding author: E-mail: Habiddin_wuni@um.ac.id
}

Received: 03-18-2021

\begin{abstract}
Virtual and concrete models have been of interest in chemistry teaching to improve students' understanding of a three-dimensional representation of chemical concepts such as symmetry. This study aims to determine the effectiveness of using concrete and virtual models on students' understanding of symmetry. Students' understanding was also explored in light of their spatial ability. The study was conducted using a quasi-experimental design with 62 students as participants. Two different instruments, spatial ability and understanding of symmetry tests, were employed for data collection. Data analysis was performed using the Pearson product-moment correlation and two-way variance analysis test. The results showed the virtual model's contribution to improving students' understanding of symmetry is higher than that of the concrete model for both students with high spatial ability (HSA) and low spatial ability (LSA). Also, the better students' spatial ability, the better their understanding of molecular symmetry.
\end{abstract}

Keywords: Virtual Model, Concrete Model, Molecular Symmetry, Spatial Ability

\section{Introduction}

Molecular symmetry is an essential topic that is generally provided for university students taking an inorganic chemistry course. Symmetry governing the physical and spectroscopic properties of molecules provides clues regarding electronic and molecular structure as well as the way of reaction carried out. ${ }^{1}$ The topic is also essential in other chemistry branches, such as predicting optical activity in organic chemistry. ${ }^{2}$ Recognizing and understanding three-dimensional representations is a paramount ability to understand chemical concepts, particularly symmetry. Having good visual-spatial thinking skill is highly required to build a robust understanding of symmetry. ${ }^{3}$ Also, students should visualize and predict three dimensions of unfamiliar motion. ${ }^{4}$ The sound understanding of symmetry and 3D orientation of chemical compound and reaction contributes to students' success in learning other chemi- cal concepts. ${ }^{5}$ It is the building blocks for understanding modern molecular chemistry. ${ }^{6}$ Difficulty in understanding symmetry contributes to the barrier to understand other chemical concepts. ${ }^{7}$ These statements confirm that a good understanding of symmetry is essential for chemistry students. Visualising a two-dimensional object to a three-dimensional object requires several thinking tasks. Firstly, the interpretation and understanding of different charts must be done correctly before translating them into three-dimensional forms. ${ }^{8-11}$ Secondly, converting abstract objects into real objects. ${ }^{12}$ However, the results of our preliminary observations showed that the vast majority of students could not predict the shapes of molecules and determine the angle of the molecular shape. These inabilities could be rooted in students' tendency to describe molecular shapes based solely on Lewis structures without considering molecules' position as three-dimensional objects. ${ }^{13}$ Also, the explanation of abstract concepts in text- 
books is generally only based on two-dimensional visualisations,${ }^{14}$ which distort mental models.

Recent studies ${ }^{11,15-17}$ revealed that students still find it challenging to visualise two-dimensional forms implying an insufficient spatial ability. This insufficient ability could be rooted in difficulty identifying the rotation axis position relative to the object based on the visualisation of objects before and after rotation and difficulty visualising an object's appearance after rotation and reflection operations. ${ }^{18}$ Students' spatial abilities contributing to students' understanding of chemistry and other science disciplines ${ }^{19}$ are categorized into three types covering Spatial Visualization (SV), Spatial Orientation (SO), and Spatial relations (SR). ${ }^{17,20,21}$ They define SV as an ability to transform a two-dimensional (2D) object to the three-dimensional (3D) representation; SO as the ability to imagine an object from a different perspective; and SR as an ability to visualize the movement or operation of an object including rotation, inversion and reflection. The contribution of these spatial abilities in improving students' understanding of chemistry has been reported in some pieces of literature. For example, students with high SR ability demonstrated a strong understanding in determining the $2 \mathrm{D}$ and $3 \mathrm{D}$ rotations of $\mathrm{CH}_{3} \mathrm{COOH}{ }^{21}$

Students' ability to build mental visualization of molecular shapes or spatial ability can be improved by optimizing their representational competence. ${ }^{10,22,23}$ The term representational competence describes an ability to understand chemical phenomena and translate the phenomena from one representation to other, for example, connecting macroscopic to symbolic and or submicroscopic and vice versa, drawing and predicting chemical reactions phenomena. ${ }^{22,24,25}$ The contribution of this competence towards students' success in science learning has been of concern in many areas ${ }^{26,27}$ including science, technology, engineering, and math (STEM), ${ }^{28}$ and physics. ${ }^{29}$ This competence has also been considered as an essential factor to be improved in all educational levels. ${ }^{28}$

Representational competence can be improved by applying a virtual model-assisted learning strategy or concrete model. ${ }^{10,23,30}$ In particular, plenty of previous studies confirmed that the concrete model had been a powerful tool to promote students' representational competence. ${ }^{31}$ Virtual or concrete model-assisted learning provides visio-spatial information better than without using a model. ${ }^{10}$ Virtual and concrete model which interact with students' visual sense $\mathrm{e}^{32}$ and haptic and visual sense $\mathrm{e}^{10}$ respectively, facilitate students to recognize the symmetry element and symmetry operation of a molecule. For example, in some molecules such as $\mathrm{H}_{2} \mathrm{O}$ and $\mathrm{NH}_{3}$, the $C_{n}$ axis is quite clear to be recognized, but some molecules are challenging. ${ }^{33}$ Therefore, drawing a molecule in a particular orientation will provide a better way to catch one rotational axis. ${ }^{33}$ Surely, the 3D representation such as virtual and concrete model will serve the better view to assist students in recognizing the rotational axis. For ex- ample, identifying the $\mathrm{C}_{3}$ and $\mathrm{C}_{2}$ axes of the $\mathrm{CH}_{4}$ molecule will be challenging without having the virtual or concrete model displaying the three-dimensional orientation of the molecule. Research comparing the effectiveness of using virtual and concrete models in chemistry has been carried out. $8,10,34$ The results found different outcomes. Fjeld ${ }^{34}$ found that the concrete model demonstrated better support to students' achievement than a virtual model.

On the other hand, Abraham et al. ${ }^{8}$ and Stull \& Hegarty ${ }^{10}$ found an insignificant difference between the two models. The difference in cognitive construct when using the two models could be a complementary aspect for each other. Fjeld ${ }^{34}$ revealed that the virtual model requires more cognitive tasks than the concrete model. Therefore, combining the two models is reasonable exercises. ${ }^{10}$ The works focusing on designing instructional video and other virtual representation to improve the quality of teaching and learning has been carried out ${ }^{35}$ including how students interact emotionally to the virtual representation. ${ }^{36,37}$

Several approaches have been applied in teaching symmetry as well as overcoming students' unscientific understanding of the topic including hands-on symmetry project, ${ }^{38}$ three-dimensional (3D) models, ${ }^{39-41}$ virtual laboratories, ${ }^{3}$ common daily objects, ${ }^{42}$ and drawing $2 \mathrm{D}$ projection. ${ }^{43} \mathrm{~A}$ study focusing on the difference between using concrete and virtual model is limited. Therefore, this study aimed to explore how concrete and virtual media affect the students' understanding of symmetry and how students' spatial ability influences it. The result of this study will provide a vital perspective to be applied in the teaching of symmetry. The virtual model in this study is an online multimedia application provided by the website https://symotter.org/. Meanwhile, the concrete models were created by students representing molecular geometries.

\section{Methodology}

\section{1. Research Design and Participants}

This study employed a quasi-experimental design and involved two classes/groups (with 31 students for each) of third-year students at the Chemistry Department, Universitas Negeri Gorontalo taking chemical bonding. In this university, symmetry is one of the topics discussed in the chemical bonding course. The convenience sampling technique was applied because the study was carried out in a natural setting in which the authors were not allowed to randomize the classes. Students experiencing concrete model were named Students with Concrete Model (SCM), and students experiencing virtual models were named Students with Virtual Model (SVM).

\section{2. Procedure}

This study was carried out according to the following procedure. 


\section{- Preliminary test}

Before the treatment, the two groups were given a preliminary test to determine whether they posed an equal academic ability. The test covered the geometry molecule topic, a prerequisite topic, before embarking on the symmetry class. The homogeneity test using Levene's Test $(P>$ 0.05 ) showed that the prior academic ability between the two groups was equal.

- Intervention

The intervention in the form of a guided inquiry teaching approach was applied for the two groups. Syntaxes or stages of the inquiry teaching for the two groups were the same and described as follow: orientation, exploration, concept formation, and application. In the orientation stage, the lecturer provides a brief explanation of the topic that will be discussed. In the exploration stage, students explored a task given. For example, in the teaching of reflection through a plane of symmetry, students observed the molecular structure of $\mathrm{PCl}_{3}$ and predicted any possible symmetry operation of the molecule. In the concept formation stage, the lecturer provided several stimulus questions to understand the concept. For example, identify the rotation operation of the $\mathrm{PCl}_{3}$ molecule, the main axis (if any), etc. Students are encouraged to employ the media (concrete model for SCM and virtual model for the SVM). In the application process, students clarify their answer in class discussion with the guidance of the lecturer. In addition, several exercises to reinforce students' understanding of the topic were also implemented. In this stage, the students have also employed the media to find out all the symmetry operations at the molecules.

As explained above, all the teaching experiences but the media applied in the concept formation stage and application for the two groups were the same. The two groups' symmetry teaching was carried out on the same day with the subsequent time slots to avoid interaction thread between the two groups. The virtual model was applied as symmetry learning media for the SVM class, and the concrete model was applied SCM class. The teaching of molecular symmetry to both groups was carried out in three meetings with 120 minutes for each.

\section{- Post-test}

After completing all three meetings, students' understanding of molecular symmetry was measured using a short answer test with 18 questions. The instrument is named Students' Understanding of Molecular Symmetry Test (SUMST).

\section{3. Learning Media and Instrument}

\section{3. 1. Virtual Model}

The virtual model was applied as the learning media to facilitate students' understanding of symmetry for a virtual class. The virtual models are available on the website of https://symotter.org/. The website (Symmetry@Otterbein) offers three features like the following. (1) Symmetry Tutorial provides an interactive point group that can guide the user through all elements and operations of symmetry with interactive displays and animations. (2) Symmetry Gallery is a collection of more than hundreds of unique molecules with interactive views of all elements of symmetry and animation of symmetry operations. The molecules are arranged by groups of points, so the user can select samples to show a particular element of symmetry. (3) Symmetry Challenge provides a detailed flow chart of the process of determining the point group of each molecule. Figure 1 below depicts a virtual model of molecular symmetry available on the website.

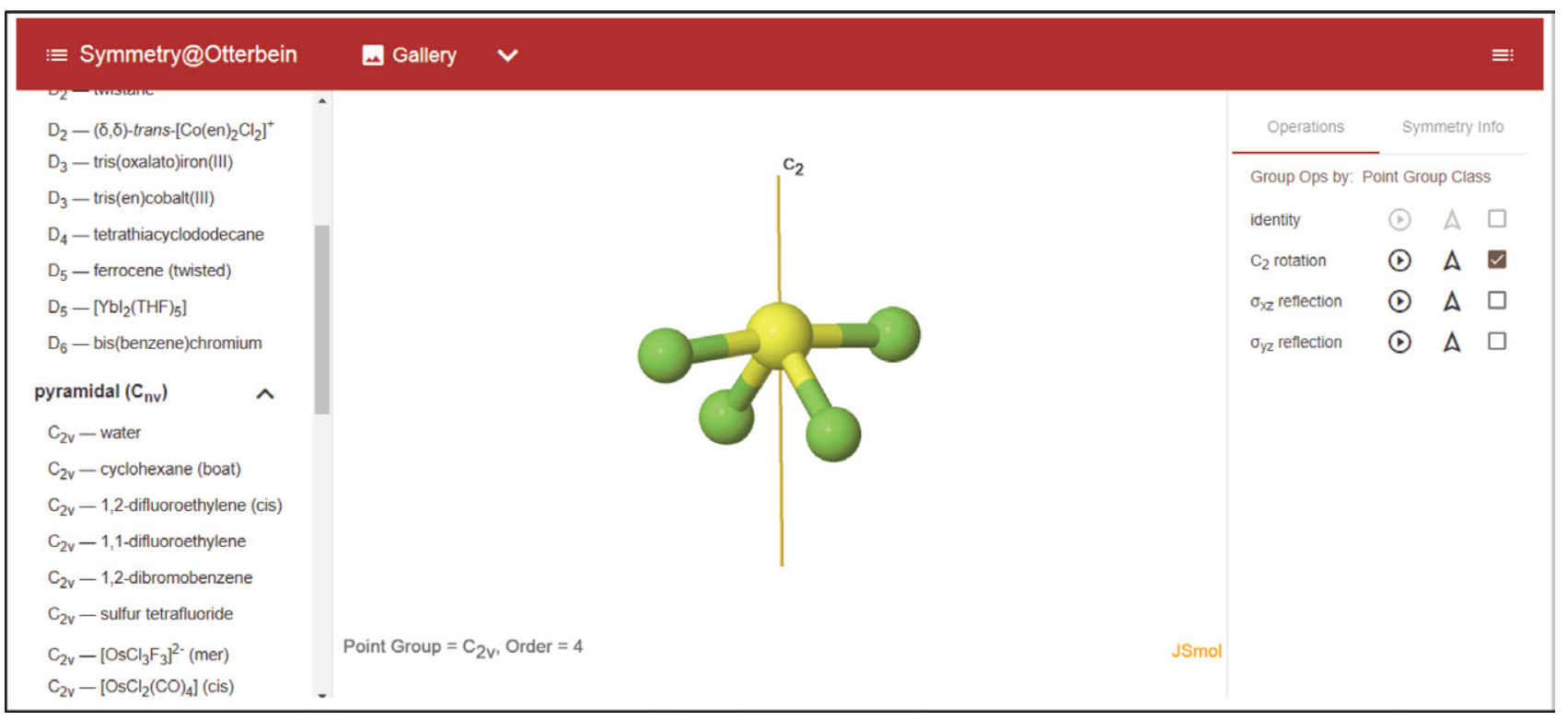

Figure 1. Example of the virtual model presented in the teaching of SVM. 


\section{3. 2. Concrete Model}

The concrete model was applied as the learning media to facilitate students' understanding of symmetry for concrete class. The concrete models were produced by utilizing daily materials such as pencil eraser and needles. Students were required to create the concrete model to build their understanding of the symmetry operation unconsciously. The molecular shape design was arranged to form an angle following the experimental molecule's angle and affect the symmetry operation.

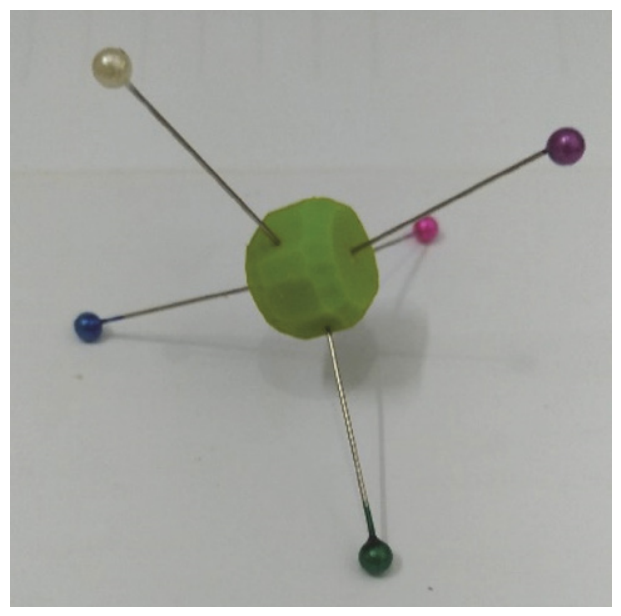

Figure 2. Example of a concrete model produced in the teaching of SCM.

\section{4. Spatial Ability Test}

The Purdue Spatial Visualization Test (PSVT) developed by Guay ${ }^{44}$ was applied to measure students' spatial ability was in a multiple-choice question and 30 items. This instrument has been the most frequent tool to be employed in the study of spatial ability. The example of a question is provided in Figure 3 below. The spatial ability test instrument has high category reliability with a value of 0.95 .
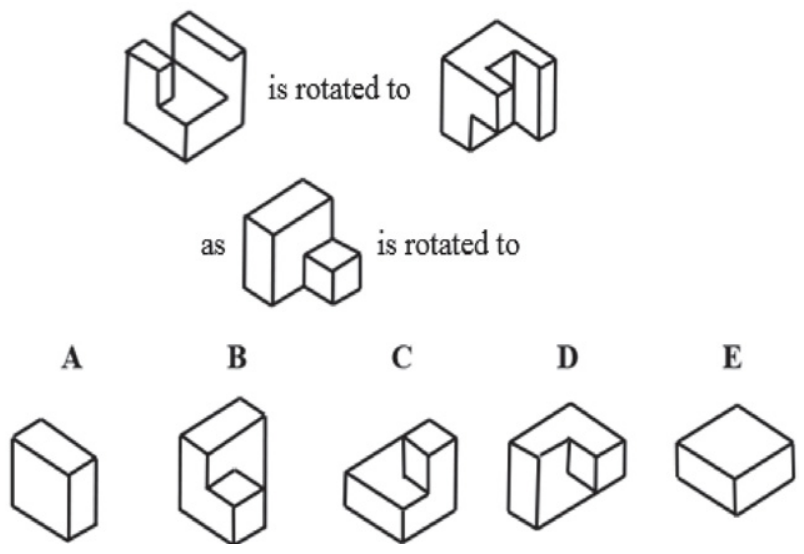

Figure 3. Example of a question in the PSVT.

\section{5. Students' Understanding of Molecular Symmetry Test (SUMST)}

Students' understanding of molecular symmetry after teaching using virtual and concrete models was measured using the SUMST. The SUMST was in the form of a short answer question and represented all symmetrical operations that exist in the molecule in depth. The test instrument consisted of 18 items with a Cronbach Alpha coefficient of 0.905 , falling in the very high category. The instrument is available on request.

\section{6. Data Analysis}

\section{6. 1. Students' Spatial Ability}

The level of students' spatial ability is categorised based on the PSVT score. Students who obtained scores above the average are included in students with high category spatial abilities (HAS). In contrast, students who obtained scores below the average are included in students with low category spatial abilities (LSA).

\section{6. 2. Students' Spatial Ability and Understanding of Symmetry}

The correlation between students' spatial ability and students' understanding of symmetry was measured using Pearson product-moment correlation. Before the correlation test performed, the prerequisite tests, including the normality test and the homogeneity test, were applied. The normality test using the Kolmogorov-Smirnov test (One-Sample KS ) obtained P >0.05, which means that the data is normally distributed. The homogeneity test using Levene's Test obtained $\mathrm{P}>0.05$, which means the data is homogeneous.

\section{6. 2. The Effectiveness of Virtual and Concrete Models on Students 'Understanding of Symmetry}

Two-way analysis of variance (ANOVA) was used to determine (1) the difference in the effectiveness of using virtual and concrete models on students 'understanding of molecular symmetry with different spatial abilities and (2) the interaction between virtual models and concrete models on students' spatial abilities in learning molecular symmetry.

\section{6. 3. Ethics Approval}

Ethical approval has been obtained from Universitas Negeri Malang and Universitas Negeri Gorontalo. All the students who participated in this study have been provided with all the information regarding the study. They have agreed to participate voluntarily by filling the consent form. 


\section{Results and Discussion}

\section{1. Student Spatial Ability Level}

Students' spatial abilities were classified into three categories, including spatial visualization (SV), spatial relation (SR) and spatial orientation (SO). ${ }^{17,20,21}$ All three categories were identified using the related type of spatial questions. Ten questions represented each category. The example portrayed in Figure 3 above is a type of SV question. The description of students' spatial ability level is presented in Table 1.

Table 1. Students' Spatial Ability Test Results

\begin{tabular}{lcc}
\hline Spatial ability category & \multicolumn{2}{c}{ Number of Students (\%) } \\
& High & Low \\
\hline SV & 77.4 & 22.6 \\
SR & 58.1 & 41.9 \\
SO & 75.8 & 24.2 \\
\hline
\end{tabular}

The table described that the number of students with high spatial level ability is always higher than that of each category with low spatial ability. The previous study ${ }^{45}$ supports this finding that spatial abilities develop well at the age 11-16.

\section{2. Spatial Abilities, Virtual \& Concrete models, and Understanding of Molecular Symmetry}

Students' responses to the SUMST instrument representing their understanding of molecular symmetry for virtual and concrete models with high and low spatial ability levels are presented in Table 2.

Table 2. Students' Responses to the SUMST and spatial ability level

\begin{tabular}{lcc}
\hline Spatial ability level & \multicolumn{2}{c}{ Students' score to the SUMST } \\
& SVM class & SCM class \\
\hline High & $X=66.20$ & $X=51.9$ \\
& $N=17$ & $N=19$ \\
& $\mathrm{SD}=13.83$ & $\mathrm{SD}=18.93$ \\
\hline Low & $X=44.34$ & $X=36.80$ \\
& $N=14$ & $N=12$ \\
& $\mathrm{SD}=21.05$ & $\mathrm{SD}=21.5$ \\
\hline
\end{tabular}

The Table 2 shows that the virtual model provided a better contribution to the students' understanding of symmetry for high spatial ability (HSA) and low spatial ability (LSA) students. This finding is in accordance with the previous research. ${ }^{10,30,46}$ The better performances of SVM students were demonstrated in several aspects. SVM group demonstrated better performance than the SCM group in predicting molecular shape, especially in determining the bond angles. The availability and accuracy of information regarding bond angle a molecular geometry cause students to become accustomed to predict molecular shape including bond angles, making it easier for students to identify molecular symmetry operations. This familiarity leads to better cognitive training and the improvement of cognitive abilities. ${ }^{47}$

Below is the different level of students' responses in predicting the shape of the $\mathrm{PFCl}_{4}$ molecule for the two groups. SVM students understood that the angle of $\mathrm{Cl}_{\mathrm{eq}}-\mathrm{P}-\mathrm{Cl}_{\mathrm{eq}}$ (eq= equatorial) would be distorted and $<120^{\circ}$ due to the difference in electronegativity between the $\mathrm{Cl}$ atom and the $\mathrm{F}$ atom, which is in the axial position. Meanwhile, SCM students assumed that the difference in electronegativity would not affect the angle of the molecule $\left(120^{\circ}\right)$ (Figure 4). Such error in determining the bond angle will lead to an incorrect choice in determining the rotation and reflection operations. ${ }^{48}$

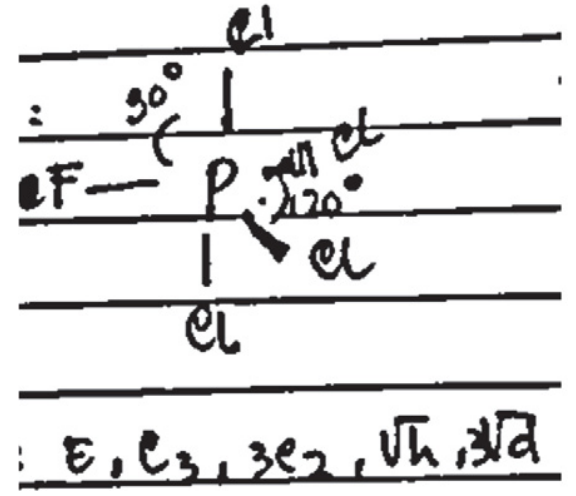

Figure 4. Example of an incorrect answer of SCM students regarding $\mathrm{PFCl}_{4}$ molecule

SVM students also identified the rotation operations through the actual rotation axis than SCM did. The limited possibilities in manipulating the movement of molecular shapes for SVM strengthen students' long-term memory retention. In contrast, the concrete model provides plenty of possibilities for SCM students to do movement manipulations of molecular shape leading to overload memory remembering these movements. The limited possibilities help students remember every detail of three-dimensional objects' movement. ${ }^{46}$ The two groups demonstrated the different responses in determining the rotational operations of the $\mathrm{SeF}_{6}$ molecule. SVM students identified that the $\mathrm{SeF}_{6}$ molecule exhibit $C_{4}, C_{3}$, and $C_{2}$ of axes rotations. Meanwhile, SCM students assumed that the molecule only exhibits $C_{3}$ and $C_{2}$ axes rotation.

SVM students are also more successful in identifying reflection operations in the mirror plane than SCM students. The virtual model's availability of mirror plane 
features (vertical, horizontal, and diagonal mirror planes) supported a better understanding of SVM students when studying the mirror plane's reflection operation. In identifying the reflection operation on the mirror plane of the $\mathrm{POF}_{3}$ molecule, SVM understood that the molecule has a vertical mirror plane at the $\mathrm{F}$ atom's corners. Meanwhile, SCM students assumed that the molecule has a horizontal and diagonal mirror plane.

The difference in students' understanding between SVM and SCM students is also described based on each topic's correct answer (Table 3). SVM students obtained a higher average score than SCM students. This fact emphasizes that the virtual model is adequate for teaching chemistry concepts involving three-dimensional objects, ${ }^{49}$ such as molecular geometry and molecular symmetry, particularly for high spatial ability students.

\section{3. The Relationship between Spatial Abilities and Understanding Molecular Symmetry}

Table 2 above also shows a contribution of students' spatial ability towards their success in understanding molecular symmetry. In particular, students with a high spatial ability (HSA) demonstrated a better understanding of molecular symmetry than low spatial ability (LSA) students, as uncovered in the previous studies. ${ }^{3,50}$ HSA students could use spatial visualization, spatial orientation, and spatial relation, strengthening their understanding of molecular symmetry operations such as rotation, reflection, inversion, and pseudo rotation operations. In determining the reflection operation on the $\mathrm{AsH}_{3}$ molecule, LSA students believed that the molecule has four mirror

Table 3. The comparison of Correct Answers between SVM and SCM students

\begin{tabular}{|c|c|c|c|}
\hline \multirow[t]{2}{*}{ No. } & \multirow[t]{2}{*}{ Sub-topic } & \multicolumn{2}{|c|}{ Correct Answers (\%) } \\
\hline & & SVM & SCM \\
\hline 1 & Predict molecular shape & 68 & 67 \\
\hline 2 & Identify the rotation operation via the actual axis of rotation & 53 & 50 \\
\hline 3 & Identify the major axes & 45 & 41 \\
\hline 4 & Identify the reflection operation on the mirror plane & 33 & 31 \\
\hline 5 & Identify any inversion operations through the centre of symmetry & 49 & 45 \\
\hline 6 & Identify the rotation operation via the pseudo rotation axis & 35 & 35 \\
\hline 7 & Predict the polarity of molecules based on the symmetry operations they have & 33 & 29 \\
\hline 8 & Predict the conservation of molecules based on the symmetry operations they have & 46 & 43 \\
\hline
\end{tabular}

The phenomena discussed above provide strong evidence of different students' understanding due to the use of virtual and concrete models in teaching molecular symmetry. Students' interaction with the concrete and virtual model may also affect the understanding of students. The flexible use of the keyboard and mouse to manipulate the 3D object movement produce a limitless interaction between students and the virtual model as much as the interaction of SCM students with the concrete model. However, the advantage of the virtual model over the concrete model is its better and more representative shape of the molecules. Two-way ANOVA confirmed the difference in students' understanding between the two groups with the F values of 5.049 at the significant level of 0.028 . The values imply the difference in students' understanding of molecular symmetry between the SVM and SCM students. The percentage of correct answer between the two groups presented in Table 3 confirms that the virtual model is more effective than the concrete model in increasing student' understanding of molecular symmetry. The test also found that there is no interaction between learning media and spatial skills ( $\mathrm{F}$ (1.62) $=0.484 ; \mathrm{P}>0.05)$. planes, including one horizontal mirror plane and three dihedral mirror planes. This error resulted from a low understanding of the spatial visualization aspect, leading to the difficulty of translating the bold visual notation code and dotted line notation in molecular structures. ${ }^{11}$

In term of the ability of spatial relations, holding this ability contributed to students' competence in manipulating representative three-dimensional objects in space. ${ }^{14}$ LSA students believed that the $\mathrm{SO}_{2} \mathrm{~F}_{2}$ molecule has a $\mathrm{C}_{3}$

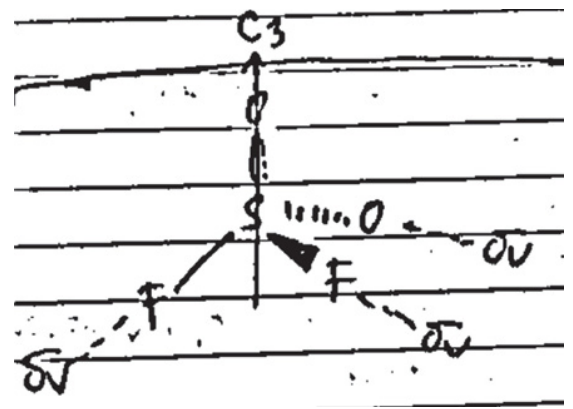

Figure 5. Example of LSA students' error in determining the rotation operation of $\mathrm{SO}_{2} \mathrm{~F}_{2}$ molecule 
rotation operation (Figure 5). This error could be the result of an inability to determine the geometry of the molecule.

The different responses between the two groups were also found when determining the rotation operation on the $\mathrm{SeF}_{6}$ molecule. Robust knowledge in spatial orientation will lead students to determine the molecular rotation operations on different axes 36 correctly. SLA students believed that $\mathrm{SeF}_{6}$ molecules only have the $C_{4}$ rotation operation as the main axis due to their inability to imagine the appearance of the $\mathrm{SeF}_{6}$ molecule from various viewpoints, which allows determining the existence of other rotation operations.

In terms of combining spatial visualization, spatial orientation, and spatial relations abilities, the discrepancy between the two groups' responses was determined by determining the rotation operation via the pseudo axis $(S n)$ of the $\mathrm{CCl}_{4}$ molecule. LSA students were unable to show a pseudo-axis rotation operation on the $\mathrm{CCl}_{4}$ molecule. Students' mistakes were shown in several ways. Firstly, they can perform rotation operations correctly but cannot for reflection operations. Secondly, they performed rotation and reflection operations correctly but could not determine the new molecule's position from a different point of view.

The findings above show that students' spatial ability correlates to their understanding of molecular symmetry both for HAS and LAS students. The better students' spatial ability, the better they understand the topic of molecular symmetry. This correlation was also confirmed by the statistical test result using Person product-moment correlation with an $r$-value of +0.395 .

\section{Conclusion}

This study confirms that the virtual model provides a better contribution toward students' understanding of molecular symmetry. Also, students' spatial ability affects students' understanding of the topic. Students' understanding of molecular symmetry increase with the increase of their spatial ability. This study implies that employing a virtual model in the teaching of molecular symmetry is a fruitful approach. Improving students' spatial ability is essential to be a solid milestone in learning chemistry concepts involving three-dimensional objects such as molecular geometry and molecular symmetry.

\section{Acknowledgements}

We thank Prof. Effendy, $\mathrm{PhD}$, for his tremendous and valuable supports in doing this study. ${ }^{26}$

\section{Reference}

1. P. Atkins, T. Overton, J. Rourke, M. Weller, F. Armstrong, Inorganic Chemistry, Oxford University Press, Oxford, $4^{\text {th }}$ Edn., 2006.
2. S. F. A. Kettle, J. Chem. Educ. 2009, 86, 634. DOI:10.1021/ed086p634

3. K. Achuthan, V. K. Kolil, S. Diwakar, Educ. Inf. Technol. 2018, 23, 2499-2515. DOI:10.1007/s10639-018-9727-1

4. B. K. Niece, J. Chem. Educ. 2019, 96, 2059-2062. DOI:10.1021/acs.jchemed.9b00053

5. S. E. McKay, S. R. Boone, J. Chem. Educ. 2001, 78, 1487. DOI:10.1021/ed078p1487

6. A. Korkmaz, W. S. Harwood, J. Sci. Educ. Technol. 2004, 13, 243-253. DOI:10.1023/B:JOST.0000031263.82327.6e

7. J. D. Dunitz, Proc. Natl. Acad. Sci. 1996, 93, 14260 LP 14266. DOI:10.1073/pnas.93.25.14260

8. M. Abraham, V. Varghese, H. Tang, J. Chem. Educ. 2010, 87, 1425-1429. DOI:10.1021/ed100497f

9. S. Padalkar, M. Hegarty, J. Educ. Psychol. 2015, 107, 451-467. DOI: $10.1037 / \mathrm{a} 0037516$

10. A. T. Stull, M. Hegarty, J. Educ. Psychol. 2016, 108, 509-527. DOI:10.1037/edu0000077

11. H. K. Wu, P. Shah, Sci. Educ. 2004, 88, 465-492. DOI: $10.1002 /$ sce. 10126

12. J. T. Olimpo, B. C. Kumi, R. Wroblewski, B. L. Dixon, Chem. Educ. Res. Pract. 2015, 16, 143-153.

DOI:10.1039/C4RP00169A

13. C. Furió, M. L. Calatayud, S. L. Bárcenas, O. M. Padilla, Sci. Educ. 2000, 84, 545-565.

14. I. Tuvi-Arad, P. Gorsky, Chem. Educ. Res. Pract. 2007, 8, 61-72. DOI:10.1039/B6RP90020H

15. M. Stieff, Learn. Instr. 2007, 17, 219-234. DOI:10.1016/j.learninstruc.2007.01.012

16. M. Stieff, S. Raje, Spat. Cogn. Comput. 2010, 10, 53-81. DOI:10.1080/13875860903453332

17. M. Harle, M. Towns, J. Chem. Educ. 2011, 88, 351-360. DOI:10.1021/ed900003n

18. H. Tuckey, M. Selvaratnam, Stud. Sci. Educ. 1993, 21, 99 121. DOI: $10.1080 / 03057269308560015$

19. M. Cole, J. Wilhelm, B. M. Vaught, C. Fish, H. Fish, Educ. Sci. 2021, 11, 4. DOI:10.3390/educsci1 1010004

20. N. Barnea, in: J. K. Gilbert, C. J. Boulter (Eds.), Developing Models in Science Education, Springer Netherlands, Dordrecht, 2000, pp. 307-323.

21. Y. Rahmawati, H. Dianhar, F. Arifin, Educ. Sci. 2021, 11, 185. DOI:10.3390/educsci11040185

22. Kozma, J. Russell, J. Res. Sci. Teach. 1997, 34, 949-968. DOI:10.1002/(SICI)1098-2736(199711)34:9<949::AIDTEA7>3.0.CO;2-U

23. M. Stieff, R. C. Bateman, D. H. Uttal, in: J. K. Gilbert (Ed.), Visualization in science education, Springer Netherlands, Dordrecht, 2005, pp. 93-120. DOI:10.1007/1-4020-3613-2_7

24. R. Kozma, J. Russell, in: J. K. Gilbert (Ed.), Visualization in science education, Springer Netherlands, Dordrecht, 2005, pp. 121-145. DOI:10.1007/1-4020-3613-2_8

25. M. Stieff, D. DeSutter, J. Res. Sci. Teach. 2021, 58, 128-156. DOI:10.1002/tea.21650

26. M. M. Cooper, M. Stieff, D. DeSutter, Top. Cogn. Sci. 2017, 9, 902-920. DOI:10.1111/tops.12285

27. A. J. Magana, S. Balachandran, J. Sci. Educ. Technol. 2017, 
26, 332-346. DOI:10.1007/s10956-016-9682-9

28. M. Stieff, S. Scopelitis, M. E. Lira, D. Desutter, Sci. Educ. 2016, 100, 344-363. DOI:10.1002/sce.21203

29. T. S. Volkwyn, J. Airey, B. Gregorcic, C. Linder, Learn. Res. Pract. 2020, 6, 88-107.

DOI:10.1080/23735082.2020.1750670

30. A. T. Stull, T. Barrett, M. Hegarty, Comput. Human Behav. 2013, 29, 2546-2556. DOI:10.1016/j.chb.2013.06.012

31. H.-Y. Chang, Sci. Educ. 2018, 102, 1129-1149.

DOI:10.1002/sce.21457

32. R. A. Ruddle, D. M. Jones, J. Exp. Psychol. Appl. 2001, 7, 286-296. DOI:10.1037/1076-898X.7.4.286

33. W.-K. Li, G.-D. Zhou, T. Mak, Advanced Structural Inorganic Chemistry, Oxford University Press, Oxford, 2008.

34. M. Fjeld, J. Fredriksson, M. Ejdestig, F. Duca, K. Bötschi, B. Voegtli, P. Juchli, in: Proceedings of the SIGCHI Conference on Human Factors in Computing Systems, Association for Computing Machinery, New York, NY, USA, 2007, pp. 805-808.

35. R. E. Mayer, J. Appl. Res. Mem. Cogn. 2021,

DOI:10.1016/j.jarmac.2021.03.007

36. A. P. Lawson, R. E. Mayer, N. Adamo-Villani, B. Benes, X. Lei, J. Cheng, Comput. Human Behav. 2021, 114, 106554. DOI:10.1016/j.chb.2020.106554

37. A. P. Lawson, R. E. Mayer, N. Adamo-Villani, B. Benes, X. Lei, J. Cheng, Int. J. Artif. Intell. Educ. 2021, 31, 134-153. DOI:10.1007/s40593-021-00238-2
38. K. Fuchigami, M. Schrandt, G. L. Miessler, J. Chem. Educ. 2016, 93, 1081-1084. DOI:10.1021/acs.jchemed.5b00325

39. A. V Savchenkov, J. Chem. Educ. 2020, 97, 1682-1687. DOI:10.1021/acs.jchemed.0c00192

40. E. B. Flint, J. Chem. Educ. 2011, 88, 907-909. DOI:10.1021/ed100893e

41. V. F. Scalfani, T. P. Vaid, J. Chem. Educ. 2014, 91, 1174-1180. DOI:10.1021/ed400887t

42. P. Jittam, P. Ruenwongsa, B. Panijpan, Biosci. Educ. 2008, 12, 1-8. DOI:10.3108/beej.12.6

43. L. Chen, H. Sun, C. Lai, J. Chem. Educ. 2015, 92, 1422-1425. DOI:10.1021/ed500898p

44. R. Guay, Purdue Spatial Visualization Test, Purdue Research Foundation, West Lafayette, Indiana, 1976.

45. H.-D. Barke, T. Engida, Chem. Educ. Res. Pract. 2001, 2, 227-239. DOI:10.1039/B1RP90025K

46. T. J. Barrett, A. T. Stull, T. M. Hsu, M. Hegarty, Comput. Educ. 2015, 81, 69-81.

DOI:10.1016/j.compedu.2014.09.009

47. S. M. Jaeggi, J. Karbach, T. Strobach, J. Cogn. Enhanc. 2017, 1, 353-357. DOI:10.1007/s41465-017-0057-9

48. Effendy, Molekul, Struktur, dan Sifat-sifatnya, Indonesian Academic Publishing, Malang, 2017.

49. A. T. Stull, M. Gainer, S. Padalkar, M. Hegarty, J. Chem. Educ. 2016, 93, 994-1001.

DOI:10.1021/acs.jchemed.6b00194

50. I. Tuvi-Arad, R. Blonder, Chem. Educ. Res. Pract. 2010, 11, 48-58. DOI:10.1039/C001046B

\section{Povzetek}

Virtualni in konkretni modeli se uporabljalo pri poučevanje kemijskih vsebin, da bi študentje lažje razumeli tridimenzionalno predstavitev kemijskih konceptov, kot je simetrija. Cilj te študije je ugotoviti učinkovitost uporabe konkretnih in virtualnih modelov pri razumevanju simetrije. Razumevanje študentov smo raziskovali tudi glede na njihove prostorske sposobnosti. Študija je bila izvedena s kvazi-eksperimentalnim načrtom, v katerem je sodelovalo 62 študentov. Za zbiranje podatkov sta bila uporabljena dva različna pristopa in sicer prostorska sposobnost in testi razumevanja simetrije. Analiza podatkov je bila izvedena s pomočjo Pearsonovega korelacijskega koeficienta in ANOVA. Rezultati so pokazali, da je prispevek virtualnega modela $\mathrm{k}$ izboljšanju razumevanja simetrije študentov višji kot pri konkretnem modelu tako za študente z visoko prostorsko sposobnostjo (HSA) kakor tudi nizko prostorsko sposobnostjo (LSA). Opazili smo tudi, da imajo boljše razumevanje molekulske simetrije tisti študenti, ki imajo boljšo prostorsko predstavo.

Except when otherwise noted, articles in this journal are published under the terms and conditions of the Creative Commons Attribution 4.0 International License 